\title{
Hearing Global Modernity: The Case of the Travelling Oud
}

\author{
Rachel Beckles Willson
}

HCM 7: 458-485

DOI: $10.18352 / \mathrm{hcm} .559$

\begin{abstract}
Musical instruments are integrated into the fabric of societies throughout the world and, like any number of objects, are adapted as they travel. In this article I place the oud (the eastern lute) in the context of a transformation that the late Arif Dirlik identified as 'global modernity', and analyze the career of the remarkable and hugely influential Iraqi musician Munir Bashir (I930-I997). I also use Bashir and his oud to nuance and extend aspects of the model set out by Dirlik which, for all its strengths, is geographically partial, and focuses strongly on the productive side of global competition and diversification. As I will demonstrate, Bashir's oud was a part of the global modernity being negotiated by actors in the Iraqi, European and American culture-political spheres. But its success reveals the partiality of those negotiations, the precariousness of globally shared power, and the divisions between cultural, political and socio-economic spheres of 'hearing'.
\end{abstract}

Keywords: global, Iraq, modernity, Munir Bashir, music, oud

\section{Introduction $^{1}$}

I would like to underline 'the hearing' here, for while cultural differences have been present all along, what distinguishes our times from times past is a willingness to listen to invocations of cultural legacies not as reactionary responses to modernity but as the very conditions of a global modernity. $\left(\right.$ Arif Dirlik, 2003) ${ }^{2}$ 
One of the memorial events held after the tragic fire at London's Grenfell Tower in June 20I7, in which more than seventy people lost their lives, was a service of remembrance in St Paul's Cathedral. It included musical performances chosen in collaboration with survivors, one of which was played on the oud by Syrian musician Rihab Azar. The oud is a much mythologized musical instrument frequently described as 'ancient' and often used in Europe to support orientalist imaginaries. But in this painful moment it contributed to a shared moment of listening that could on some level tune in to the ethnic and economic complexity of contemporary London life.

Instruments are integrated into the fabric of societies throughout the world and, like any number of objects, are modified as they travel. They may circulate as commodities or be disposed of as unprofitable; they may be transformed, inserted into different spheres of value and even given new uses. Guitars and accordions have become commodities that circulate globally. ${ }^{3}$ Other instruments, such as the ney and the shakuhachi, are part of more modest international flows, partially dependent on the diffusion of spiritual practices and their adaptations in new contexts. ${ }^{4}$ In other words, instruments have what Igor Kopytoff referred to as 'biographies'. ${ }^{5}$ And as my example above makes clear, the potential for these to be significant is contingent on shifting historical and political circumstances. Forty years before the disaster of Grenfell Tower, a fire at London's Kings Cross station took the lives of seventytwo people. But it is unlikely that in 1987 anyone would have thought of using the oud to create an atmosphere in which to remember the victims. What has changed?

When it appeared as a foreign object in early nineteenth-century Europe, the oud was appreciated primarily as something to look at or simply own: it was a museum item. Over time, however, it became something to be listened to, something that could be grasped sonically and socially. Today, no longer just a peripheral component of European imperialism, it is a constitutive part of social interactions in Europe and also North America. We might say it has become an 'actor', in a sense recognizable from Eliot Bates' work, because its increasing proliferation has been part of an envoicing and a hearing. ${ }^{6}$ There are some obvious explanations at hand: decolonization, the rise of the world music industry and the spread of the world wide web, to name a few. But the relationships between musical practices and flows of capital are variegated and complex, part and parcel of transformations on micro 


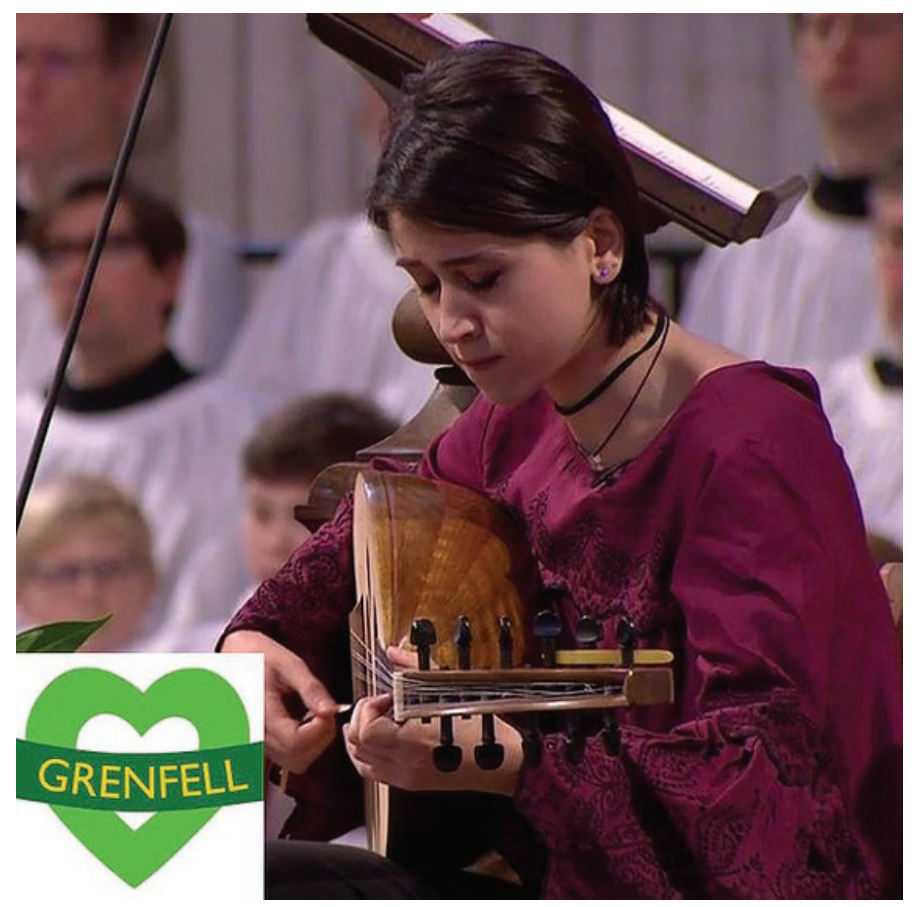

Figure I. Rihab Azar playing oud at the Grenfell Tower Memorial Service St Paul's Cathedral, June 2017. Courtesy of the BBC.

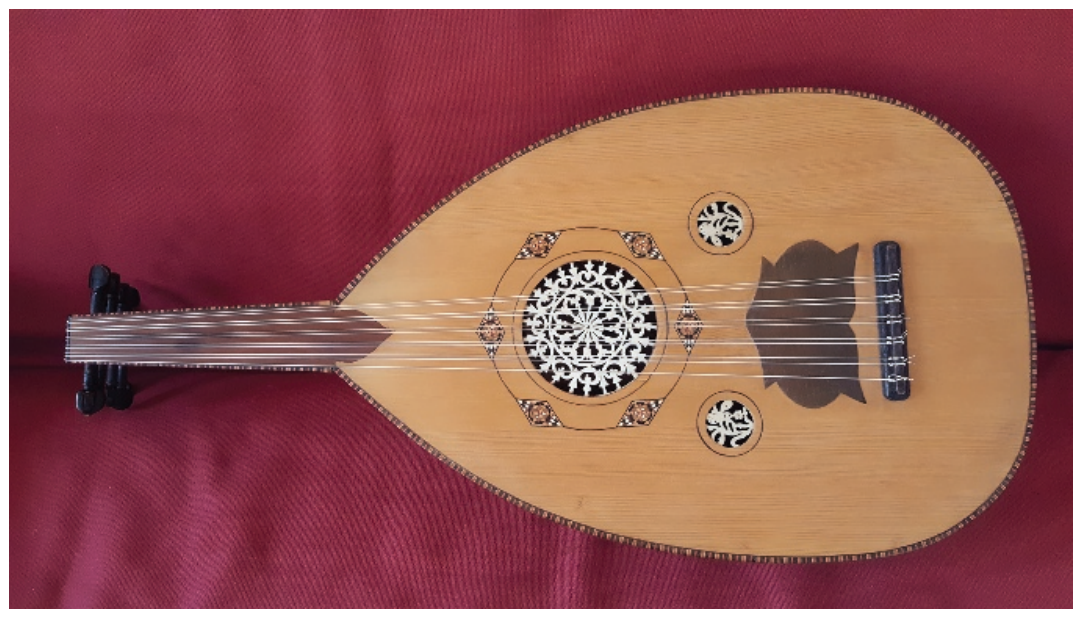

Figure 2. Oud made by Garabat de Bedrosian, Damascus 1959. 
and macro scales that, as Sebastian Conrad has argued, a truly global historical thinking must reflect. ${ }^{7}$ What interests me here is how ouds and instruments in general - are connected to uneven rights to be heard in cultural, political and socio-economic spheres.

I have two principal aims in this article. One is to place the oud in the context of a transformation that the late Arif Dirlik identified as 'global modernity', using this framework to illuminate the career of the remarkable and hugely influential Iraqi musician Munir Bashir (I930-I997). Dirlik sustains a (Marxist) view of modernity as a singular phenomenon, but takes a relational approach to its globalized form. Global modernity emerges with the growth of new capitalist economies around the world (in the wake of decolonization and the fall of the Soviet Union) and the consequent ceding of Euro-American hegemony. It is not bounded by nations, cultures, civilizations or ethnicities, but rather cuts across them as a dynamic network of institutions and practices that compete for capital. ${ }^{8}$ Connecting and dividing the world differently from the modernity of earlier periods, global modernity emerges in the I970s, precisely the decade in which the most influential oud in the twentieth century was first played in Europe - that of Bashir.

My other aim is to use Bashir and his oud to nuance and extend aspects of the model set out by Dirlik which, for all its strengths, is geographically partial and focuses strongly on the productive side of global competition and diversification. Dirlik identified people from the peripheries of Euro-American discourses demanding a 'hearing' in the centre, and argued that from the late I970s onwards there was a new 'willingness to listen' to them as aspects of the contemporary world. ${ }^{9}$ The dynamic quality of this idea is important, because it goes beyond Spivak's highly influential work on the 'speech' of the colonized. 'Willingness to listen' recognizes the importance of the context in which speech is made and sharpens thereby our sense of relationality. ${ }^{10}$ And yet, problematically, Dirlik did not elaborate his idea of 'hearing' in great detail. While my main concern here is not to enter discussions of sound that have grown up in recent years, I will suggest that Dirlik's sonic metaphors, once pursued critically, give us a sense of the partiality and destructiveness of global modernity - qualities that are implicit but under-developed in his work. ${ }^{\mathrm{II}}$

In order to begin, I present a birds-eye view of the life of the oud in the Euro-American sphere prior to the arrival of Munir Bashir. I move on to address how Bashir was presented to European publics, how he 
shaped his performances, how the material qualities of his instrument contributed to his impact and how all these elements were part of shifting spheres in international diplomacy and, subsequently, war. As I will demonstrate, the oud was a part of the global modernity being negotiated by actors in the Iraqi, European and American culture-political spheres. But its success reveals the partiality of those negotiations, the precariousness of distributed power and the divisions between cultural, political and socio-economic spheres of 'hearing'.

\section{The Oud in Euro-America: A Bird's-Eye View}

The oud was already known in Europe during Muslim rule in the South between 750 and I492, when musicians moved between urban and courtly centres in Baghdad and Seville. Ouds were fundamental both in the court and on the street, used for playing alone, accompanying individual singers and playing in ensembles. When Muslim leaders began to be gradually expelled from Europe the oud seems to have disappeared from the region. By then, however, the lute (whose name derives from the Arabic term with the definite article, i.e. ' $a$ oud') was spreading through Europe, changing as it went. Thus at the end of the eighteenth century, when European interest in West Asia began to grow, the oud could reappear as an 'other' once again, even while attractively similar to many instruments understood as European.

When Napoleon's team of scientists entered Egypt in I798 and gathered items through which to study the region's history and culture, an oud was within the collection they made. ${ }^{12}$ The instrument they brought to Europe seems to be lost (other instruments in the same batch have been preserved), but its acquisition is important to note, because it heralded the collecting culture that would eventually see the curation of ouds within international exhibitions and, later, in musical instrument museums. ${ }^{13}$ Central to this phase of interest in the oud is what Clifford identified as a particular type of domination: collecting was 'a strategy for the deployment of a possessive self, culture, and authenticity'. ${ }^{14}$ Certainly it had very little to do with listening.

From the early twentieth century onwards, however, there were increasing numbers of European as well as American spaces in which ouds could be heard. Communities of emigrants from the Ottoman Empire to North America established clubs and festivals in which music 
had a central role, frequently involving an ensemble including an oud..$^{15}$ Following the collapse of the Ottoman Empire, when the political edges of Europe were redefined with particular violence in the Greco-Turkish War, the new Greek and Turkish states effected a population exchange based on religious identity, with the consequence of approximately two million homeless refugees. Among refugee musicians were Istanbulborn oud players Grigoris Asikis and Agapios Tomboulis (Hagop Stamboulian), who began playing in Athens on the popular café scene. Nevertheless, both in North America and Europe such spaces were essentially ghettos, and saw little or no exchange between immigrant and receiving communities.

In the I950s, the emergence in North America of a multi-ethnic 'oriental' nightclub scene triggered a change, as did the growth of the recording industry. An American craze for raqs sharqi ('belly-dance') emerged, and there was a consequent surge of orientalist recordings that were conceived for, and consumed by Americans. ${ }^{16}$ Then, beginning in the I96os, a range of revival movements incorporated the oud, shifting the frames of how it could be understood. In the USA the so-called American folk movement had artists turning away from electric amplification and performing traditional American songs or dance music with acoustic guitar, and in I964 the celebrated Newport Folk Festival invited the Nubian Egyptian oud player Hamza El Din to perform. Gradually both popular and classical mainstreams came to incorporate new sounds of alterity (the Beatles' use of the sitar is a well-known example) and El Din played oud with American rock band the Grateful Dead, as well as the American string quartet Kronos Quartet.

In Greece, a movement against the cultural suppression of the country's military dictatorship (I967-74) triggered a revival that challenged the westward-looking face of Greece that had been constructed in the wake of the Ottoman Empire. It involved a reclaiming of heritage that had been alive during Ottoman times, which was still remembered by the (now elderly) refugees. ${ }^{17}$ The oud was crucial, both symbolically and in terms of its particular sound and idiomatic intonation. Even Europe's and North America's Early Music Movement involved the oud, because it triggered a rethinking of space and the reconstruction of relations with traditions considered distant, including the music from the time of the Muslim rule of Spain. ${ }^{18}$ An early example is a collaboration between the Spanish musician Eduardo Paniagua and the Sudanese oud player and singer Wafir Sheikh. ${ }^{19}$ The oud was a reminder of the 
benefits of European connections with Islamic culture: it could serve as a vehicle for cohabitation rather than conflict. It was a moment of recognition that Europe could work creatively with its neighbours.

The I960s and I970s thus reveal some important changes in the fortunes of the oud in North America and Europe, changes in which the instrument was acknowledged as a part of the European past and present in a sonic rather than purely material sense. As Dirlik put it, there was a 'willingness to listen': traditions from outside Europe were recognized as part of modernity, part of the present. The example of Munir Bashir, to which I turn next, allows us to grasp this more fully.

\section{Wanted: Arab Man with an Oud}

Behind the I960s and I970s interest in revival was the emergence of a new form of collecting, namely traditional music on record. By the I970s it was a curating trend, shaped by ideals from the academy, the archive and the museum, and, increasingly, led by organizations such as UNESCO and the International Council for Traditional Music (ICTM) ${ }^{20}$ Recordings on LPs were frequently accompanied by studies of the sound, understood variously as useful in academic settings or for a more general public. The ethos was in many cases encyclopaedic, and early in the I970s a loosely affiliated circle of researchers was looking for a man and an instrument that could represent Arab culture. Essentially they sought a figure for Arab music equivalent to the Indian musician Ravi Shankar, whose recordings on sitar had been in circulation since the early I960s.

The main actors were Simon Jargy, Professor of Islamic and Arab Studies at the University of Geneva, Paul Rovsing Olsen, composer, ethnomusicologist, Keeper of the Danish Folklore Archives and Chairman of the International Council for Traditional Music, and JeanClaude Chabrier, independent researcher. They were to be joined in time in their promotion of Bashir by Hassan Touma, a Palestinian musicologist based in Germany, and the Syrian-French Şerif Khadnazar, Director of the Maison de la Culture in Rennes, France.

Jargy and Olsen seem to have made initial contact with Bashir in I970, when he was based in Beirut working for the music distribution company established by his older brother Jamil (to Jamil, a gifted violinist, oud player and composer based in Baghdad, I return below.) 
They invited him to Europe for three solo concerts, which took place in I97 I in Geneva, Holstebro (Denmark) and Versailles (Paris). Shortly afterwards he was able to release a vinyl recording of the Geneva concert with liner notes by Jargy, and then another vinyl recording in the following year, again with notes by Jargy, this time of recordings made in Beirut. ${ }^{21}$ By 1974 Bashir was in Europe again to perform at the first Festival des Arts Traditionnels in Rennes, organized by Khadnazar. In 1977 he was back performing in Geneva.

Crucially, and typically for the collectors of their age, these appreciators of the oud were concerned with sound very explicitly, and sought to conceptualize and theorize it in writing. They were interested in the music theory that underpinned the music Bashir played the little-known world of maqam, or 'mode', which had a logic very different from European theories of sound. And more broadly, they were interested in how this music should be appreciated, how it should be listened to and understood in the context of the Arab world. Having selected Bashir, they were gatekeepers, but also mediators, persuading Europeans to lend an ear to foreign sounds.

Olsen, by then an experienced ethnomusicologist with particular knowledge of the Gulf States, had an interest that was primarily music-encyclopaedic. He was a key actor in the publication of ethnomusicological sound collections that characterized the moment of a new listening, and noted that Bashir's first recording 'exemplifies one of the great traditions of the world'. ${ }^{22}$ But his argument did not relegate this music to the past. On the contrary, he was concerned to point out its contemporaneity. Bashir's performances could not be understood as typical of the Iraqi school of $o u d$, he said, but were rather 'fascinating examples of Arab music invented by a great musician who with thorough knowledge of the surviving traditions is trying to open new ways to keep those traditions alive. ${ }^{23}$ As Dirlik argued, in the era of global modernity, 'traditions no longer imply a contrast with modernity ... [t]hey point not to the past but, taking a detour through the past, to an alternative future'. ${ }^{24}$ Olsen's interest was in positioning Bashir's work as a part of a developing situation, shaped by an individual in the present.

In the writings of Jargy and to some extent Chabrier, however, there was a broadly orientalist contextualization, which referred not to the contemporary Arab world, or even present-day Iraq, but to the oud's central position in the music life of Baghdad during the Abbasid era 
(eighth-thirteenth centuries). This enabled them to promote Bashir in reference to the most celebrated oud player of that era, Ishak al-Mawsilli (767-850). al-Mawsilli had founded a school of oud playing and was also associated with a music theory based on the oud itself. This was known as 'the theory of fingers and courses', because it was drawn from the positions of fingers on each of the double strings. ${ }^{25}$ For Jargy and Chabrier, Bashir could be linked firmly to al-Mawsilli (and, with his musical father, also al-Mawsilli's musician father), because like them some eleven centuries earlier, he was from Mosul. His oud could be presented as the central instrument of the Golden Age of Arab culture, and also the root of the music-theoretical system in which he improvised, maqam. It was the materialization of an otherwise abstracted system.

These two writers also had a broader narrative, nonetheless, one that would feed neatly into the globalizing trends of the time. Jargy used the concept 'oud' to encompass all instruments of the same 'family' (plucked chordophones with necks), claiming that the oud was celebrated not only in the Abbasid empire, but had been a favourite instrument of the Sumerians and Assyro-Babylonians of ancient Mesopotamia (the site of modern-day Iraq), and had gone on to be played in the Chinese Han Empire. ${ }^{26} \mathrm{He}$ and others also invoked the oud's earlier arrival in Europe, not to revitalize links around the Mediterranean basin but to position. Bashir as a descendent not only of al-Mawsilli but also of Ziryab, the much mythologized musician who is purported to have brought the oud from Baghdad to Europe in the early ninth century. ${ }^{27}$ The model offered by Ziryab was a figure that travelled and was implicitly or explicitly hybrid, ideally suited to Dirlik's 'willingness to listen', which endowed authority to figures who had precisely this quality. They were understood as having been transformed by the colonial experience and thus carried the mark of hybridity that qualified them for membership of global modernity. ${ }^{28}$ Bashir could emerge as a figure who could represent the music of the Arab world for Europe as it reconfigured its postcolonial place on the globe.

For both Jargy and Chabrier, there was something else at stake as well. Jargy had grown up in Mardin (Syria), in an environment deeply shaped by Syriac Christianity. His initial music research had focused on Syriac liturgical music before he shifted focus towards popular sung poetry in Lebanon, Syria and Iraq. Chabrier meanwhile had developed a line of research focusing on the Christian church, and would go on to found C.H.R.I.S.T.O.S., an organization dedicated to the research 
and 'safeguarding' of Eastern spiritual traditions. His work reveals his concern than Islamic societies were doing too little to preserve their traditional musics. ${ }^{29}$ In short, both Jargy and Chabrier reveal a concern with Christian communities of the Middle East and some ambivalence, at least, about Islamic practices.

Certainly the emerging discourse, while generalizing about the Middle East, made no case for listening to Islam, the predominant religion of the region. In fact, its promotion of a more broadly religious ethos seems to have worked well to displace any such idea. Jargy led the way in liner notes for the first vinyl releases, arguing that music had a divine status and that the oud, and Arab music, were palpable evidence of that. ${ }^{30}$ In his text he drew freely on mythology, legend and centuries-old cosmologies from Islamic philosophy, without identifying his sources. The first oud, he explained, had been made by one of Adam's sons, Lamek; and the music-theoretical system underpinning Bashir's improvisations had originated in the sounds of the twelve springs of water flowing from the rock in the Sinai desert struck by Moses.

It is difficult to gauge the extent to which other actors really believed these claims, but they contributed to the popular discourse that made Bashir's music familiar enough to be listened to very widely, giving it a seriousness that compensated for its unfamiliar qualities. Importantly, moreover, it could be combined powerfully with postcolonial critique, as we can trace in a review by leading Parisian music critic, ethnomusicologist and composer Maurice Fleuret, who had a long-standing interest both in new European art music and musical traditions of Africa and Asia. ${ }^{31}$ In his appreciation of Bashir published in 1975 he identified a need for Europe to develop a new form of 'hearing' to rid itself of its superiority complex and prejudices. Listening to Arab music was key, because while the music of India, Iran and Indonesia was already accepted and supported in Europe, 'countries with Arab music culture remain victims of our aural prejudices'. He then made a connection between the most progressive music of the time, the so-called 'avantgarde', and music of the East:

this superiority complex, which dates not only from colonization, is bowing to the double pressure of avant-garde music and ancient Far Eastern traditions, both of which imply a radically different listening. We come to see that a bare vocalise, the imperceptible caress of the fingers on the string, can say as many things as the most monumental symphony. 
At the end of the article he repeated Jargy's invocation of Moses, and encircled Bashir and his ensemble in an inspiration of maqam that was divine. This was presumably intended to make the music seem attractive to a popular readership, appealing to the 'nativist traditionalism' identified by Dirlik as a strand within globality. ${ }^{32}$ Fleuret's main point, after all, was not a spiritual one. His interest was self-critique and indeed self-transformation: Europe was due to reconfigure its place in the globe and listening to Munir Bashir was one way to do that. His arguments exemplify the 'proliferation of challenges to Eurocentrism' identified by Dirlik because they strove not only to "combat the "colonization of the mind"', but also to effect a decolonization of the ear. ${ }^{33}$

\section{Playing the Part}

Bashir was an ideal reflection for European interest in Oriental Christianity, as he had grown up with a grandfather who was a learned priest in the Syriac church in Mosul where his father was also deacon. Nevertheless he responded well to broader European religious imaginings and indeed he magnified them. Perhaps he was already aware of the success of Ravi Shankar and imagined for himself a parallel role, as Chabrier would later suggest. ${ }^{34}$ Or perhaps he was himself interested in exploring various spiritual traditions (one of his later supporters, Khaznadar, who invited him to the festival in Rennes, recalled that Bashir's favourite authors were Sufi mystics). ${ }^{35}$ In any case, he was quick to incorporate a vaguely spiritual dimension into his public narrative in Europe, and indeed into his physical appearance. He switched, for instance, from wearing a modern suit and tie to appearing in a traditional full-length robe, the gandoura. ${ }^{36}$ This enabled him to represent a loosely-defined spiritual figure, to enact the role and the perspective according to which, as he put it in interview, 'the Orientals in general, and Arabs in particular, are spiritually inclined people', and to note that they inhabited the region where the great religions originated. ${ }^{37} \mathrm{He}$ had realized that a claim for a physical connection with the origin of Christianity endowed him with authority in Europe.

$\mathrm{He}$ also cultivated an atmosphere akin to a ritual for his concerts, prior to each piece sitting before the audience at length in silence and avoiding any form of amplification. ${ }^{38} \mathrm{He}$ requested very low lighting and even perfume in the air - his preference was for incense, central 
to the Orthodox rite. Within his improvisations he left long silences and long moments of resounding strings, both of which were entirely novel in Arab concert music in general, and oud-playing traditions in particular. ${ }^{39} \mathrm{He}$ also took a particularly ascetic approach to listening in the concert hall. At his first appearance in Rennes in 1974 he stopped playing to command, in Arabic, that listeners refrain from tapping in time to the music, and he threatened to stop playing if it happened again. ${ }^{40}$ With this act, he diverged fundamentally from the practice of participatory listening characteristic of many traditional Arab settings, and opted instead for the European concert aesthetic. Thus, even while his promoters sought to challenge Eurocentrism through him, Bashir's affirmed European modernist regimes of listening. ${ }^{4 I}$ The irony is not unusual. As Dirlik has observed, some critical moves 'bolster the claims of the colonial modernity that they seek to challenge'. They are threads in the new discourse of modernity, uneven results of intersections between precolonial, colonial and postcolonial legacies..$^{42}$

By the mid-I970s Bashir had taken up European discourses of revivals, presenting himself as the first person to resuscitate the model of instrumental soloist, lost since Ziryab and al-Farabi in the ninth century. Since beginning in the I940s, he claimed, he had been imitated by many. ${ }^{43}$ When reporting to the American press about his work with stone tablets which were understood to preserve songs from ancient Babylon, he remarked 'Babylon was the center of the world's civilization, arts and culture and it is right that it regain that fame again' [my italics]. ${ }^{44}$ If his concern with the ancient past was a part of asserting Iraq's national modernity, this particular ancient nation was not only valuable to itself. Rather, it was the 'cradle' of civilization in general. Bashir's ambitiously global statement claimed that Babylon had been, and would be again, a value for the 'world'. Its very stones needed to be heard.

\section{Getting Iraq Heard}

Situating Bashir in modern Iraq opens up a very different perspective, but also allows us to understand the strength of his claims. They emerge, as we will see, from a period of political transformation and economic growth, in which Bashir acquired authority that carried him through the ensuing decade when the economy foundered. 
In the I970s there was considerably less interest in traditional Arab musics in Iraq than there was in parts of Europe..$^{45}$ But when in 1973 the governing Ba'ath Party formed a new cultural council as part of a broad political consolidation, Bashir was invited back from Beirut to Baghdad to become a member. It is likely that the European construction of Bashir as the new al-Mawsili or Ziryab had reached Iraq, and fed into the new cultural politics emerging there. In similar vein, Iraqi strong man Saddam Hussein would later historicize himself as a leader who followed on directly from Abbasid rulers. ${ }^{46}$ In 1977 Bashir was placed in command of a new department of music within the committee (Iraqi National Music Committee), effectively taking charge of all the state institutions involved with music, including education, research and performance. ${ }^{47}$ The Iraqi National Music Committee was incorporated as a member into UNESCO's International Music Council, which connected Bashir to a global institution for the development of traditional music.

The effect of this can be traced on two interlocking levels, national and international. Bashir used the resources he had to shape the cultural sphere of Iraq according to European, or elite international values. For example, the second international oud congress and festival he directed in Baghdad in 1978 was dedicated to presenting the influence of ArabIslamic music on European civilization in the medieval era. Chabrier suggested that the theme was taken directly from the Rennes Festival of 1977 directed by Khaznadar, Musiques d'Orient, musique médiéval occidentale: leurs rapports aujourd'hui ${ }^{48}$ implying that Bashir was staging Iraq for an international audience. A decade later, shortly after the Babylon festival of 1989 , his work was indeed recognized with the UNESCO Grand Prix. ${ }^{49}$

In his review of the 1978 festival, Chabrier was critical of how the oud was presented to the world. The festival's theme did not relate to the oud's Abbasid heritage, he noted, nor did it acknowledge the musicians who had been Bashir's 'assets' at the start of his career, namely his brother Jamil and the founder of Iraq's modern oud school, Şerif Muhiddin Haydar. ${ }^{50}$ Chabrier also noted that none of the celebrated oud soloists from the Arab world were present to perform at the festival. He illuminated how Bashir had become, in Baghdad, a singular figure of authority, and it is not difficult to imagine him as a figure of 'hate' in some circles in Iraq, as Khaznadar later described. ${ }^{51}$ His is a beautifully clear example of the new divisions of the world in the era of global 
modernity: in the place of past divisions between colonizer and colonized are divisions within particular societies, separating the 'personnel of global power' and those disenfranchized from it. ${ }^{52}$ Bashir was among the former: not only did he have support and protection of Saddam Hussein but, for the international stage, he edited out the context in which he had developed, and appeared both as the leader of music in Iraq and as the sole musical bridge between Iraq and Europe.

For some, the career he had developed was very clear. He could be understood, as a New York critic observed, as a modern-day Paderewski, the Polish pianist who became Prime Minister. ${ }^{53} \mathrm{He}$ was no longer al-Mawsili or even Ziryab, neither based in Baghdad nor building music bridges over the Mediterranean basin. He was a musical leader in a global political sense, an institutionalized musical figure making a claim to participate in the distributed network of modernity. As Dirlik put it, modernity 'is not a thing but a relationship, and being part of the relationship is the ultimate marker of the modern' ${ }^{54}$

\section{Critical Contexts for the Bashir Phenomenon}

Just as for the mythologized case of Ziryab, there is much to be learned from situating the heroic figure of Bashir within the context that Chabrier missed in the 1978 oud festival. The first point to note is that the transformation in Iraq's oud culture had happened long before, when Bashir was a child. In I936, King Ghazi established the Institute of Fine Arts in Baghdad and invited Şerif Muhiddin Haydar, son of an Arab prince who had lived most of his life in Istanbul, to lead it. Şerif Muhiddin Haydar established a seminar for oud at the Institute, and ushered in a professional, institutional training in Arab and Ottoman traditions that had been until then entirely absent there. His skill drew both on years of study in the Ottoman capital Istanbul and his sojourn in the USA, during which he attempted to develop a career both as a cellist and oud player. Despite Bashir's claims, it is probably Şerif Muhiddin Haydar to whom credit should go for introducing solo oud recitals to Iraq, given that in the I920s he performed as a soloist in New York while in the orbit of Godowski and Padarewski, and then spent some years in Ataturk's Turkey, in which there was support for some western-style solistic concertizing. Notoriously, he drew from his studies of the cello in extending the technical potential of the oud, not only developing a 
virtuosic style in his compositions and performances, but also tuning his oud strings to a pitch that seems to have been exceptionally high at the time..$^{55}$ This trend in high tension tuning shaped the sound of the instrument in a new solistic role and it facilitated high-speed, flashy styles of playing.

The growth of an oud 'school' that could be identified as solistic also depended on another key figure in Bashir's life, namely his prodigiously talented brother, virtuoso oud player and violinist, Jamil Bashir, who died prematurely in I977. It had been Jamil's talent that led the family to move to Baghdad in I937, where he studied violin and oud at the Institute of Fine Arts with the newly-arrived Şerif Muhiddin. Jamil himself seems to have established a position of immense authority and control. Already Inspector of music in schools, and Director of music on the radio, when Şerif Muhiddin left in I948, he succeeded him as Director of music at the Institute of Fine Arts. ${ }^{56}$ At that point Munir was I8, and both the talent and exuberant personality of Jamil may have kept him in the shade for some time. Certainly little is known of his early years.

Most importantly of all, Munir's young adulthood must be understood through the broader frame of intense of modernization in Baghdad. For Iraqis of varied political persuasions, the $1948-58$ period represents an iconic time of development and optimism, even a 'Golden Age' of modernity and cosmopolitanism. An immense increase in oil revenues and prosperity led to extreme socio-political and economic contrasts typical of capitalist expansion and ascent. On the one hand there was a range of progressive, modernizing currents accompanied by utopian visions for the country. At the same time, thanks to political violence and corruption, much of the population was disenfranchized from the boom. At the heart of the inequalities were the nationalist vision and practices of the state, which were sectarian even while rhetorically upholding secularism.

In this period a strong desire emerged among visual artists and writers to create a new and identifiably Iraqi culture. The Baghdad Modern Arts Group (founded in I95I) drew on ancient artefacts from the region Assyrian, Babylonian, Abbasidian - to define an 'Iraqi' heritage in painting, but using reference points from modern European art. For example, painter Jawad Salim had studied in Paris and Rome. Central to literary developments was shi'-r al-hurr (the free verse movement), which can be discovered in the work of poets such as Nazik al-Malaika, 
Badr Shakir al-Sayyab and 'Abd al-Wahhab al-Bayati. Crucial to their thinking was an immersion in literature from Europe and the Americas, and a strong desire to dismantle traditional forms of the Arabic canon.

Modernization in the music scene was shaped substantially by the exodus of the Jewish communities, whose instrumentalists and patrons had been important in sustaining the Iraqi Maqam (a traditional vocal repertoire accompanied by an instrumental ensemble known as chalghi baghdadi). From the I930s onwards, Jews suffered violent harassment in response to antagonism towards the Zionist movement in Palestine, exacerbated by Nazi propaganda. Following the war in Palestine and the establishment of Israel, the Iraqi government initiated a process of ethnic cleansing: the majority of Jews renounced their citizenship (and their property) and left the country. Whereas in 1947 the Jewish community was an estimated II7,000 people, by I952 it had almost completely disappeared, and Iraq had lost part of its richest and most highly-educated population..$^{57}$ The musical life in particular was greatly reduced, and yet development in oud playing allowed it to be sustained in new ways..$^{8}$ The oud was incorporated into the traditional chalghi ensemble, for example. Iraqi Maqam melodies were being incorporated into the new sphere of solo oud performance and developed in the style of taqsim (improvisation). In short, a combination of developments in oud playing, and the changed environment for the vocal tradition, emerged as a strongly modernist musical trend that was unique to Iraq. With the support of Jargy, Khaznadar and Chabrier, in the hands of Munir Bashir it developed an international appeal.

One more important contextual thread is worth drawing out from behind Munir, namely the world he discovered when he first broke away from Baghdad and made an investment in Europe. This was in I962, when he was accepted as a student at the Liszt Academy in Budapest in the composition class of Ferenc Farkas (1905-2000)..$^{59}$ This period of study in Budapest may not have been immensely useful at first. He did not complete the undergraduate programme for which he enrolled, ${ }^{60}$ for instance, and the nationalist Soviet context was not one in which the oud could be embraced very fully. Eventually, however, the Hungarian style of incorporating traditional music in nationalist programmes may have been a valuable model to Bashir in later years within the Iraqi National Music Committee, when he led a traditional music ensemble and tour Europe with it in the I970s. Nevertheless, even this needs 
tempering with Iraq's broader history: the National Folk Ensemble was already founded in I97I, before Bashir had returned from Lebanon. ${ }^{61}$

All these contextual details are important, because they alert us to the richness of the period in Iraq prior to which the European 'willingness to listen' emerged, in the model offered by Dirlik. It was during the Kingdom that the foundations for Iraq's oud culture were laid, and this grew for some decades in the care of Şerif Muhiddin and Jamil Bashir. Iraq's booming economy in the I 950 os and onwards led to a proliferation of cultural activity. Munir Bashir emerged from within strong currents of creative work in Baghdad, and then became one of the (few) Iraqi beneficiaries of the new openness emerging in Europe and beyond. However, by the I990s, the period central to Dirlik's thinking, Iraq was becoming isolated from the network of global actors. As I will argue in the conclusion, a careful situating of Bashir and his oud in this changing context allows us a freshly nuanced understanding of 'global modernity'.

\section{Bashir's Oud: A Modern Instrument}

Before going on to that conclusion, however, it is important to look closely at one of the central actors in this whole story, the oud that Bashir played in Europe in the I970s. Ultimately, in the context of the historical orientalizing with which it was presented, this may provide the most startling and indeed important story of all. It had been made in I 957 by Baghdad luthier Mahir Muhammad Fadil Hussain (henceforth Muhammad Fadil), and seems to have been the outcome of several design experiments typical of the modernizing currents of I950s Iraq mentioned above.

Two changes are particularly obvious on comparing it with contemporary instruments from Cairo, Damascus or Istanbul. First, the traditionally round sound holes with intricate rosettes have been replaced by larger, open oval sound holes. Second, gone is the bridge glued to the face, to which the strings are secured: instead the strings are attached to the base of the instrument, passing over an unfixed ('floating') bridge like that of the cello or even mandolin. These two changes are related to another alteration that is not visible: the internal bracing of the instrument has been altered, necessarily, to accommodate the new sound holes. The result is something sturdier than the traditional oud, and also significantly different in potential. 


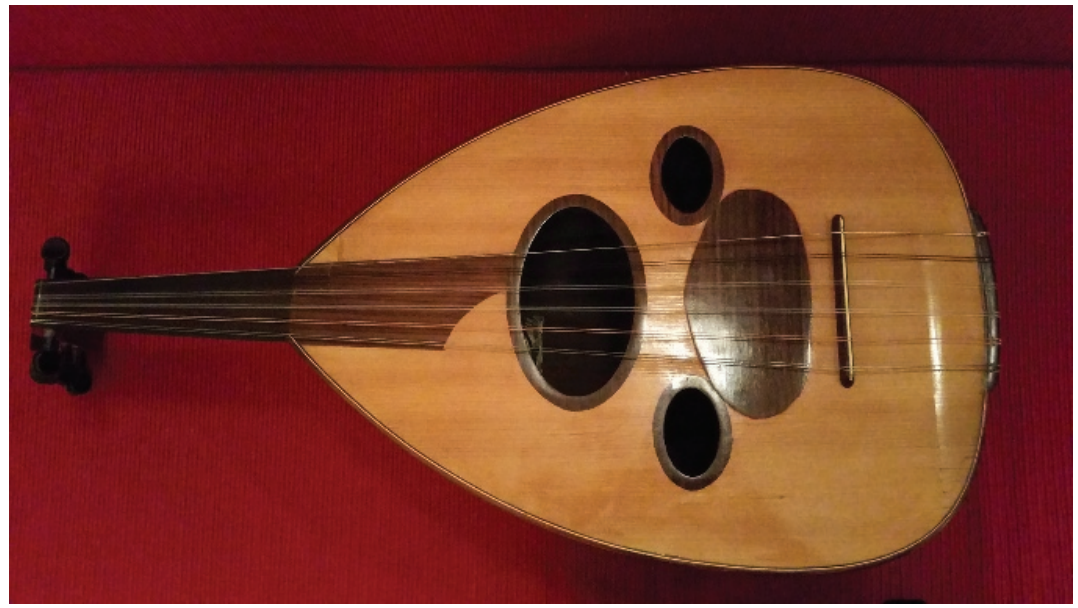

Figure 3. Oud made for Munir Bashir by Muhammad Fadil, Baghdad, 1957.

Bashir began experimenting with a different oud earlier on, commissioning the same luthier to make him an instrument in preparation for his first trip out of Iraq, when he went to Istanbul in $1954 .{ }^{62}$ The result was the first oud with ovular sound holes and the 'moon' cut-out from the fingerboard on the face of the oud. ${ }^{63}$ But it did not serve him well. When he went to Istanbul he was invited to play a fifteen-minute radio broadcast, and he offered one of his compositions ("from the East to al-Andalus') and then headed to Beirut ${ }^{64} \mathrm{He}$ had hoped to record for the radio songs with the Lebanese singer Fairouz, along with some of his own compositions. It seems that these projects were both postponed because the bridge snapped off the oud, taking part of the soundboard with it and thus shattering the instrument. ${ }^{65}$

When Munir returned to Baghdad, Muhammad Fadil repaired the instrument, but three years later he had perfected another, the one described above. In its technical innovation, breaking away from established Arab models, this instrument comes in line with iconoclastic developments in the fine arts and literature described above. By securing strings to the body of the instrument and raising them with a moveable, 'floating' bridge resting on the face, he eliminated the torsion on the face. This and other changes result in a transformed oud: the strings transfer string vibrations to the sound board in a different manner, the new bracing creates a different resonance inside the sound box, and the 
instrument is far louder than most ouds of the period. Paradoxically, this oud facilitated a style of playing slowly and quietly, leaving time left for atmospheric echoes and silences in the newly adapted melodies of Iraqi Maqam. Loudness may be associated with modern power in a brute sense, but its powerful resonance enabled Bashir to play softly, and to command attention in an apparently spiritual way. As we have seen, this had an intense appeal to European listeners.

\section{Conclusion: Instruments in Global Modernity}

In examining the transformations that allowed the oud to become a global actor I have drawn very usefully on Dirlik's thinking even while, as indicated above, the case of Iraq requires that a substantial nuance be made to his chronology. Iraq's international capitalist economy, expanding through oil reserves from the I950s onwards, predates the rise of the Southeast Asian economies of the late I970s and I980s that underpin Dirlik's theory of 'global modernity'. Similarly, the attention of European listeners such as Olsen, and Bashir's acquisition of the role of managing national heritage through the UNESCO International Music Council, are anticipations. Moreover, if we follow Iraq into the I990s, the period in which Dirlik identifies global modernity expanding and solidifying, we observe the decline of Iraq's global reach. Importantly, however, the biographies of (national) cultural artefacts are not necessarily homologous with shifts in global power. I follow the biographies of two particular ouds to elaborate this final point.

The first is the instrument developed by Bashir and Fadel in the I950s. Aligned in its impact with the ascent of Saddam Hussein, who was instrumental in the coup that brought the Ba' ath Party to power in I968 and was President of Iraq I979-2003, the instrument was part of the national claim to the international stage of economy, politics and culture. It exemplifies an object acting on behalf of national globality, to which its very materiality was well suited. Its sheer loudness is suitable for large performing spaces and many contexts of urban music making, and its construction is sturdy, making it less prone to damage in transit; its high-tension string tuning facilitates the virtuosic style for which many soloists strive. It is thus the most suitable technology for western-influenced conservatoire training, which is in itself bound up in the elite culture of modernity. The oud performance by Syrian 
Rihab Azar in London in 2017 with which I opened this article is exemplary. Azar, like other graduates of the Damascus Conservatoire, plays 'the Iraqi oud', which has become independent from Iraq as a place. ${ }^{66}$ Today it is made by luthiers in Belgium, Germany, Greece, Hungary, Lebanon, Syria, Tunisia, Turkey and the USA (and likely elsewhere).

Traditional Syrian ouds, meanwhile, have suffered a different fate, as exemplified by the biography of an instrument caught up in the nineteenth-century collecting cultures of Europe that I outlined above. The Donaldson Museum of London's Royal College of Music, established in I884, predominantly contained European instruments, but included a small group from other parts of the world, including an oud, which was photographed in the first catalogue and misidentified as a seventeenth-century Persian lute. ${ }^{67}$ The attribution suggests the compiler of the catalogue recognized the refined craft of the piece, which has a virtuosic construction in multiple filaments of different types of wood, and that he sought to explain it by making a connection with an

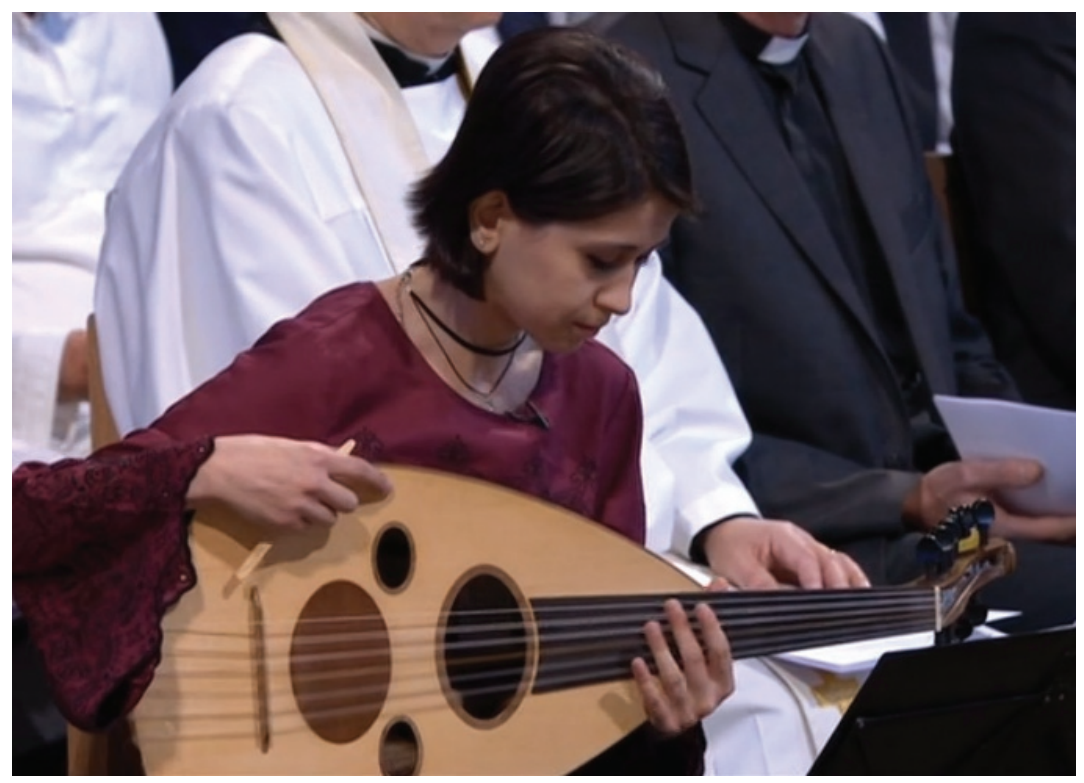

Figure 4. Rihab Azar playing oud at the Grenfell Tower Memorial Service St Paul's Cathedral, June 2017. Courtesy of the BBC. 
ancient civilization that was broadly recognized and celebrated. At that time, Anglophone music research had not yet made any link between the Arab oud and the European lute. It is testament to a period both unwilling to listen and unwilling to read, because the instrument has a label on the inside revealing the Syrian maker, Yousif Nahat, as well as the year and place it was made (I878, Damascus).

While in this article I have concentrated on the case of Bashir, and public spaces of oud hearing, the period of global modernity has witnessed a parallel transformation in the life of the oud, namely the rise of a new, private collecting culture. During the late I970s and I980s, musicians from the Palestinian territories and Syria who lived in or were moving to Europe and America, collectively (if unintentionally) triggered a fascination for historical ouds among players and expatriates more broadly. The main focus of their attention was on the Nahat family, whose members made furniture and ouds well into the twentieth century. Nahat ouds were numerous a century ago, widely present in family homes in Lebanon, Palestine and Syria. But over time many were lost, and as players left the region and their ouds entered America and Europe, increasingly they became collectors' objects. Yousif Nahat, who made the oud in the Royal College of Music's Donaldson Museum, was likely a member of this celebrated Nahat family. Until the instrument was recognized in 20I6, the oldest ouds known to have been made by the family were made by Rufan and Abdou Nahat (Ikhwan Nahat: the Nahat brothers), who founded their carpentry workshop in I880. ${ }^{68}$

Despite its evident importance, at first glance the biography of this particular oud is as unfortunate as those modelled on Bashir's oud were fortunate. The ignorance and colonial relations that characterized the nineteenth-century and much of the twentieth century prevented it from being recognized as a gem from Damascus. ${ }^{69}$ While its value now is self-evident, insufficient care over its I40 years in London have led its wood to dry out, so that today it is warped so badly as to render repair highly risky..$^{70}$ It will remain silent.

On another level, however these two oud biographies are closely aligned, and allow us to complicate Dirlik's vision of expanding global capitalisms. They remind us of another aspect of the dynamic he identified, one that Iraq and Syria currently seem to share and exemplify: destruction. During Iraq's war with Iran I980-8, austerity and military mobilization led large numbers of the population to flee the country. 
Saddam Hussein continued to receive support from the international powers, which were most concerned to isolate Iran; but when Iraq invaded Kuwait, the UN Security Council imposed a total blockade on trade. The resultant isolation was devastating for the Iraqi economy, society and culture. Iraq had been excluded, abruptly, from the world market on which it depended for its oil revenues. Western powers shifted allegiance fully away from Iraq in the years following Bashir's death in I997, and once the country had been invaded and occupied in 2003, it was knocked right out of the competition for global power. The oud model developed by Fadel and Bashir is thus a trace of a place that was not able to sustain its earlier claim to the world of global capitalism, even while it plays a role in the ongoing globalization of capital elsewhere. Similarly, Nahat ouds are the material traces of a time when Damascus sustained a deeply-rooted sophistication in craft that has now been almost entirely expelled from the region. Both Iraqi and Syrian ouds have come to stand for countries that have been all but obliterated in the rise of global modernity.

The oud has offered us a fresh way of reading the challenges of modernity today, a modernity that is global, yet partial, and still in many ways colonial. While we do listen to the 'cultural legacies' of others today, as Dirlik observed, we are often listening to their tragedies as we do so. These tragedies have indeed become "the very conditions of a global modernity'. ${ }^{71}$

\section{Notes}

I Research for this article was funded by a Major Research Fellowship from the Leverhulme Trust.

2 Arif Dirlik, 'Global Modernity? Modernity in an Age of Global Capitalism,' European Journal of Social Theory 6:3 (2003), 284.

3 See discussions by Andy Bennett, and Kevin Dawe, Guitar Cultures (Oxford, 200I); Marion S. Jacobson, 'Notes from Planet Squeezebox: The Accordion and the Process of Musical Globalization', The World of Music 50:3 (2008), 5-I4; Kevin Dawe, The New Guitarscape in Critical Theory, Cultural Practice and Musical Performance (Routledge, 20I7).

4 See, for example, Jay Keister, 'The Shakuhachi as Spiritual Tool: A Japanese Buddhist Instrument in the West', Asian Music 35:2 (2004), 99-I3I; Steven Casano, 'From Fuke Shuu to Uduboo: The Transnational Flow of the 
Shakuhachi to the West', The World of Music 47:3 (2005), I7-33; Banu Senay, 'The Fall and Rise of the Ney: From the Sufi Lodge to the World Stage', Ethnomusicology Forum 23:3 (2014), 405-24. For a broader study of internationalized music-spiritual practices incorporating instruments see Deborah Kapchan, Traveling Spirit Masters: Moroccan Gnawa Trance and Music in the Global Marketplace (Middletown CT, 2007).

5 Igor Kopytoff, 'The cultural biography of things: commoditization as process', in Arjun Appadurai (ed.), The social life of things: Commodities in cultural perspective (Cambridge, I986), 64-94.

6 Eliot Bates, 'The Social Life of Musical Instruments,' Ethnomusicology 56: 3 (2012), 363-95. Instruments' imbrication in local politics has been a topic of research for some years. See for example Anahid Kassabian, Ubiquitous Listening: Affect, Attention, and Distributed Subjectivity (Berkeley, London, 2013), 30-I; Kevin Dawe, Music and Musicians in Crete: Performance and Ethnography in a Mediterranean Island Society (Lanham MD, 2007); John Baily has referred to the dotar as the voice of Herat: Music of Afghanistan: Professional Musicians in the City of Herat, vol. I (Cambridge, I988), I58.

7 Sebastian Conrad, What is global history? (Princeton, 2016).

8 Dirlik, “'Global Modernity”?', 277.

9 Arif Dirlik, 'The Postcolonial Aura: Third World Criticism in the Age of Global Capitalism', Critical Inquiry 20 (Winter I994), 329; see also 'The End of Colonialism? The Colonial Modern in the Making of Global Modernity', boundary 2 32: I (March 2005), 284.

Io Gayatri Chakravorty Spivak, 'Can the subaltern speak?,' Can the subaltern speak? Reflections on the history of an idea (New York, I988): 2 I-78. Spivak herself shifted to a more explicitly relational position in the I990s, emphasising the conditions of possibility for being heard. See 'Subaltern Talk: Interview with the Editors (I993-94)' in Donald Landry and Gerald Maclean (eds) The Spivak Reader: Selected Works of Gayati Chakravorty Spivak (New York, London, I996), 287-308.

I I For two contrasted examples of work on listening, see Veit Erlmann (ed.) Hearing cultures: Essays on sound, listening and modernity (Oxford, 2004) and Peter Szendy and Jean-Luc Nancy, Listen: A history of our ears (New York, 2009).

I 2 A description and drawings of the oud appear in Volume 7 of the multivolume Description de l'Égypte that was co-authored by Napoleon's team. The account of music in Egypt is by musician and writer Guillaume André 
Villoteau (I759-I839), and is in Book I3. For the chapter on oud see Guillaume André Villoteau, 'Description historique, technique et littéraire des instruments de musique des orientaux', Description de l'Égypte (Paris, I 809-22), 22 I-46.

I3 See Rachel Beckles Willson, 'Alexandria to Brussels, I839', https:// oudmigrations.com/2016/03/o2/alexandria-to-brussels-I 839/ (accessed 26 December 2017) and Karim Othman-Hassan, 'The oldest surviving oud?', https://oudmigrations.com/20 I6/03/05/770/ (accessed 26 December 20 I 7 ).

I4 James Clifford, 'On Collecting Art and Culture', in The predicament of culture: twentieth-century ethnography, literature, and art (Cambridge MA, London, 2008), 2 I 8.

I 5 For a valuable presentation of early recordings, see Ian Nagoski, To What Strange Place: The Music of the Ottoman-American Diaspora, I916-29 (New York, 2008).

I6 Anne Rasmussen, “An Evening in the Orient”: The Middle Eastern Nightclub in America' Asian Music 23:2 (I992), 63-88 at 65.

I7 For a detailed study of the Greek revival see Eleni Kallimopoulou, Paradosiaka: Music, Meaning and Identity in Modern Greece (Aldershot, 2009).

I 8 From the I970s onwards classical musicians returning to (previously neglected) instruments such as the harpsichord, using gut strings (rather than metal ones) on stringed instruments, adopting a lower pitch for tuning, and developing a lighter playing style. It may be understood as a response to over-rapid urbanization, cultural homogenization and environmental anxiety, a concern about direction forward at the expense of life and indeed environmental quality. For a discussion of the heritage industry (including historical performance movements) from this and other perspectives see John Butt, Playing with History: The Historical Approach to Musical Performance (Cambridge, 2002), I65-2 I7.

I9 Dwight Reynolds, 'The Re-Creation of Medieval Arabo-Andalusian Music in Modern Performance', Al-Masāq 2 I:2 (2009), I75-89.

20 Steven Feld and Annemette Kirkegaard, 'Entangled Complicities in the Prehistory of "World Music": Poul Rovsing Olsen and Jean Jenkins Encounter Brian Eno and David Byrne in the Bush of Ghosts', Popular Musicology Online 4 (20I0), http://www.popular-musicology-online. com/issues/o4/feld.html, accessed 24 February 20I9. Jennifer Post, Ethnomusicology: A Research and Information Guide (New York and London, 2013), I09-32. 
2 I Iraq. Ud Classique Arabe Par Munir Bashir (Paris, I97I); Simon Jargy, Munir Bachir "Rècital a Genève” (Paris, [1972]).

22 Poul Rovsing Olsen, 'Iraq: ud classique arabe par Munir Bashir by Simon Jargy; Escalay; TheWater Wheel; Oud Music from Nubia by Hamza El Din', Ethnomusicology I7:3 (I973), 576.

23 Ibid.

24 Dirlik, 'The End of Colonialism?', 6.

25 The only detailed information about this theory of modes is found in a text by Yahya ibn 'Ali al-Munajjim (d.9I2). For a detailed discussion of this text see Owen Wright, 'Ibn al-Munajjim and the Early Arabian Modes', The Galpin Society Journal I9 (I966), 27-48. For a broader contextualization, see Amnon Shiloah, 'The Arabic Concept of Mode', Journal of the American Musicological Society 34: I (I98I), I9-42.

26 Simon Jargy, 'Iraq. Ud Classique Arabe Par Munir Bashir', liner notes to vinyl publication, Iraq: Ud Classique Arabe Par Munir Bashir.

27 Chabrier claimed this of Jargy's initial presentation of Bashir. For discussions of the myth of Ziryab see Dwight F. Reynolds, 'Al-Maqqarī's Ziryāb: The Making of a Myth', Middle Eastern Literatures I I:2 (2008), I75-89; Carl Davila, 'Fixing a Misbegotten Biography: Ziryāb in the Mediterranean World', Al-Masāq 2 I:2 (2009), I 2 I-36.

28 Dirlik, 'The End of Colonialism?', i6.

29 (C.H.R.I.S.T.O.S., Centre pour l'Histoire, la Recherche, l'Illustration la Sauvegarde des Traditions de l'Orient spiritual (http://christos.fr/)). See also Jean-Claude C. Chabrier, 'Problèmes contemporains du musicien et de la musique dans le monde Arabe Oriental selon l'ecole de Bagdad. Cherif Muhieddin, Jamil Bachir, Munir Bachir', [Contemporary problems of musicians and music in the Eastern Arab world and the Baghdad school: Şerif Muhieddin, Jamil Bashir, Munir Bashir.] Ethno-psychologie: Revue de psychologie des peuples 32:I (I977), 37-67.

30 Jargy, 'Iraq. Ud Classique Arabe Par Munir Bashir'.

3I Maurice Fleuret, 'L'Irak, Capitale Rennes. Deuxieme Festival Des Arts Traditionnels. Maison De La Culture De Rennes', La nouvelle Observateur (2 I April i875), 88.

32 Dirlik, 'The End of Colonialism?', ıo.

33 Dirlik, “'Global Modernity”?', 283.

34 Jean-Claude C. Chabrier, 'New Developments in Arabian Instrumental Music', The World of Music 20: I ( I978), 94-I09, at IOI.

35 Chèrif Khaznadar, 'Munir Bashir, L'homme', Cahiers de musiques traditionnelles II (I998), 3. It may have been audience members who 
revealed his path: after the first Geneva concert, one stated that Bashir's playing had brought him closer to God than ever before. See Munir Bashir, Musiqi Al-hikmah: Mudhakkirat, al-Ṭabah al-'Arabiyah (Beirut, I996), I 27.

36 Laurent Aubert, The music of the other: new challenges for ethnomusicology in a global age (Aldershot, 2007), 38.

37 Munir Bashir and Habib Touma, 'Interview with the Iraqi Ud Virtuoso Munir Bashir', The World of Music 27:2 (I975), I6.

38 'Munir hated microphones, he would always refuse amplification in his concerts'; Laurent Aubert, personal communication to the author, March 2019.

39 Habib Hassan Touma, The Music of the Arabs (Hal Leonard Corporation, 2003), I48; Berhard Holland, 'Music Noted in Brief; Munir Bashir of Iraq Plays Oud Recital', The New York Times February 23, I988. As Holland put it, 'one noticed especially Mr. Bashir's pauses between phrases as if to allow what came before to sink into the surrounding silence.'

40 Khaznadar, 'Munir Bashir,' I.

4I For a classic discussion of the development of modern listening, see James H Johnson, Listening in Paris: A Cultural History, (Berkeley etc, I995).

42 Dirlik, “'Global Modernity”?', 283 and Dirlik, 'The End of Colonialism?', I9.

43 Lauren Aubert, “'L'art du maqam. Entretien avec Munir Bashir réalisé à Genève le I9 mars I977', Cahiers d'ethnomusicologie I I (20I I): I-6 at 3; Munir Bashir and Habib Hassan Touma, 'Interview with the Iraqi Ud Virtuoso'.

44 'Babylonian Culture Lives Again', St Louis Post-Dispatch, Monday September I8, I989, 3 (no author).

45 Aubert, 'L'art du maqam', I-2.

46 Charles Tripp, A History of Iraq (New York, 2007), 2 I 7.

47 Scheherezade Hassan, 'Non-assistance à trésor en danger: À propos des archives sonores de Bagdad. Un témoignage', Cahiers d'ethnomusicologie 24 (20I I), I9I-204, at 20 I.

48 Jean-Claude Chabrier, 'Le Congrès international de la musique et le festival du ud (Bagdad, Ier-7 décembre I978)', Revue de musicologie 65: I, (I979), $76-9$.

49 Khaznadar, 'Munir Bashir,' 4.

50 Chabrier, 'Le Congrès international de la musique et le festival du ud'.

5I Khaznadar, 'Munir Bashir,' 4.

52 It is what Dirlik refers to as 'the universalization of the contradictions of a capitalist modernity’. Dirlik, 'The End of Colonialism?', 7. 
53 Holland, 'Music Noted in Brief'.

54 Dirlik, “'Global Modernity”?', 279.

55 See Rachel Beckles Willson, 'Munir Bashir and the Iraqi oud', for discussion. https://oudmigrations.com/20I9/02/25/munir-bashir-and-theiraqi-oud/ accessed 26 February 2019.

56 Junaid Bashir, 'Interview with the author', New Jersey, November 2016.

57 Moshe Gat, The Jewish Exodus from Iraq, I948-I95 I (Taylor \& Francis USHoboken, I997); Tripp, A History.

58 Yeheskel Kojaman, The Maqam Music Tradition of Iraq (London, 200 I), 48-50.

59 Diploma programmes at the Liszt Academy were exclusively in western classical music, available to students with advanced training who passed rigorous entrance examinations. Bashir was not trained as a composer in the western classical tradition, and could not therefore have been accepted on the basis used for standard students. But Iraq's government from I 958 until I963 had a strong relationship with the Soviet Union and his acceptance can be understood within the framework of agreements between communist states. Hungarian universities (including the Liszt Academy) took on large numbers of students from the Soviet region for political diplomatic reasons.

60 Munir Bashir is included on the list of all foreign students attending the Academy from I945 to I965, namely as having begun in I962 but having dropped out ('kimaradt'). A Liszt Ferenc Zenemüvészeti Főiskola Jubileumi Ismertetője as Alapítás 90. Évfordulója Alkomából I875-I965 (Budapest, I965), 78.

6I Hassan, 'Non-assistance à trésor en danger', I93

62 Bashir, Musiqi Al-hikmah: Mudhakkirat, I04.

63 Omar Bashir (conversation with the author, Budapest, September 2015.

64 In Istanbul he made contact with the Turkish Mesut Cemil Bey (son of the famous Tanburi Cemil Bey) who had taught 'cello and joza in Baghdad. Mesut Cemil held a key position at the radio.

65 Bashir, Musiqi Al-hikmah: Mudhakkirat, I04.

66 It is the standard instrument at the Damascus Conservatoire, as is the tuning favoured by Munir Bashir. This involves the top string on f'. For the Syrian context I am grateful to Rihab Azar and Samir Azar: personal communications, July 2016.

67 This was printed by Waterlow \& Sons Limited, for private circulation only. Catalogue of the Musical Instruments and Objects forming The Donaldson Museum. Presented to His Royal Highness the Prince of Wales K. G. 
(President of the Royal College of Music) on May $2^{\mathrm{ND}}$ I 894. The donor acknowledges help in compiling the catalogue from A. J. Hipkins and Captain C. R. Day. Two copies of the Catalogue are held in the Donaldson Museum at the Royal College of Music. It is most likely that of the two people who helped compile the catalogue, Hipkins, author of a book on early instruments, was responsible for captions relating to the lutes.

68 For articles relating to this instrument see Rachel Beckles Willson 'Damascus to London, I880', https://oudmigrations.com/2016/o3/o9/ damascus-to-london-c-I880/ and Karim Othman-Hassan 'Oud oldest Nahat', https://oudmigrations.com/2016/o3/og/our-oldest-nahat/ (both accessed 26 December 2017).

69 For a discussion of European involvement in the war in the Syrian region see Leila Tarazi Fawaz, An Occasion for War: Civil Conflict in Lebanon and Damascus in I860 (Berkeley, Los Angeles, I994).

70 The rise of global networks of sales which has facilitated growth of the elite market in America and the Gulf, in part on internet auctions sites and marketplaces. Nahat ouds that could be bought for \$200 dollars in the I980 can now fetch up to $\$ 25,000$.

7I As Dirlik notes, the militarism of U.S. foreign policy can be readily connected to the loss of Euro-American hegemony. Dirlik, 'The End of Colonialism?', 5 .

\section{About the Author}

Rachel Beckles Willson is Professor of Music at Royal Holloway, University of London, where her teaching reflects research in music of Hungary, the former Soviet Union and the Arab world, with questions relating to nationalism, imperialism and material culture. Her most recent monograph is Orientalism and Musical Mission: Palestine and the West (Cambridge, 20I3). For her work on travelling instruments see www.oudmigrations.com. Since Spring 2017 Beckles Willson has been working in eastern Sicily, undertaking research within musical and broader educational projects with young asylum-seekers, mainly from sub-Saharan Africa (see www.todayisgood.org). She is also an active musician and composer. E-mail: r.beckleswillson@yahoo.co.uk. 